\title{
Determination of the Genetic Variation within the Egg Parasitoid, Trichogramma brassicae, Bezdenko (Hymenoptera: Trichogrammatidae) Populations in Düzce Province, Turkey
}

\author{
Abdurrahman Sami Koca* Mustafa İmren Halil Kütük \\ Department of Plant Protection, Faculty of Agriculture and Natural Sciences, Bolu Abant İzzet Baysal University, Bolu, Turkey
}

Received: $15.02 .2018 \quad$ Accepted: 17.04 .2018

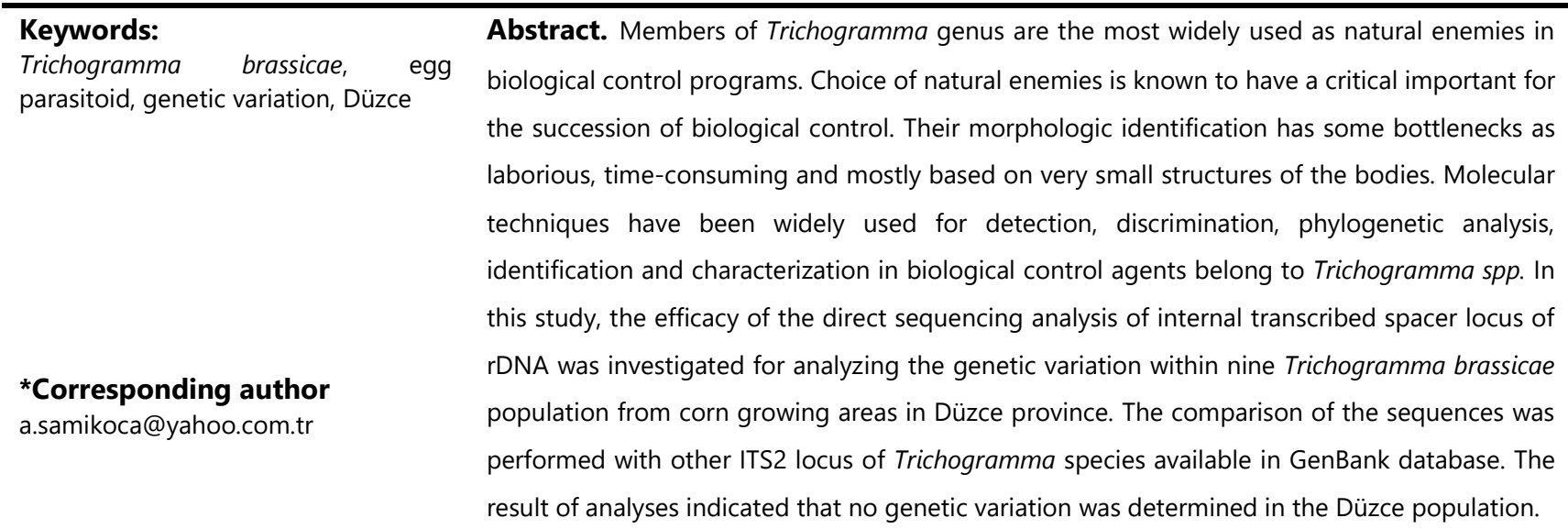

\section{Yumurta Parazitoiti, Trichogramma brassicae Bezdenko (Hymenoptera: Trichogrammatidae)'nin Düzce illindeki Popülasyonları İçerisindeki Genetik Varyasyonların Belirlenmesi}

Anahtar kelimeler:

Trichogramma brassicae, yumurta parazitoiti, genetic varyasyon, Düzce
Özet. Trichogramma türleri, biyolojik mücadele programlarında en çok kullanılan doğal düşmanlardandır. Doğal düşmanın seçiminin, biyolojik kontrolün başarısı açııından kritik bir öneme sahip olduğu bilinmektedir. Bu cinse bağı türlerin morfolojik teşhisleri zahmetli olmaları, zaman kaybı oluşturmaları ve vücut yapılarının oldukça küçük boyutlarda olmasına bağlı olarak problem oluşturmaktadır. Moleküler teknikler, Trichogramma cinsine ait biyolojik kontrol ajanlarında tespit etme, ayırt etme, filogenetik analiz, tanımlama ve karakterizasyon için yaygın olarak kullanılmaktadır. Bu çalışmada, Düzce ilinde mısır yetiştirilen alanlardan elde edilen dokuz Trichogramma brassicae popülasyonunun genetik varyasyon analizi için rDNA'nın ITS bölgesinin doğrudan sekanslama analizinin etkinliği araştırımıştır. Sekansların karşılaştırılması, GenBank veri tabanında mevcut olan Trichogramma türlerinin ITS2 bölgeleri ile gerçekleştirilmiştir. Analiz sonuçları, Düzce popülasyonlarında genetik varyasyonun tespit edilmediğini göstermiştir. 
Koca et al., Determination of the Genetic Variation within the Egg Parasitoid, Trichogramma brassicae, Bezdenko (Hymenoptera: Trichogrammatidae) Populations in Düzce Province, Turkey

\section{INTRODUCTION}

The genus Trichogramma belongs to the Trichogrammatidae family, which comprises of 80 genera and about 620 species. (Pinto and Stouthamer 1994). Trichogramma Westwood (Hymenoptera: Trichogrammatidae) species which are egg parasitoids have been used as biological control agents for more than 100 years and these species are polyphagous egg parasitoids on ten insect orders, containing Diptera, Lepidoptera, Hemiptera, Coleoptera, Neuroptera and Hymenoptera (Smith 1996).

Among the 180 Trichogramma species identified, the 70 of them are used in control of insect pests in agro-ecosystem (Li 1994). This genus has been very effective in biological control especially Lepidopteran pests. It is thought by researchers that this genus contains a large number of cryptic species because the general morphology within the group is similar (Knutson 1998). Trichogramma species are difficult to determine because of their small size and low interspecific morphological character leading to many diagnosis problems (Nagarkatti and Nagaraja 1977; Smith and Hubbes 1986). Previously, diagnosis of these species has been based chiefly on the male genitalia and the male antennae (Nagarkatti and Nagaraja 1977; Pinto 1999). According to recent studies, they have been focused on the use of mtDNA$\mathrm{COI}$ and rDNA-ITS2 regions for species diagnosis. The rDNA occurs of three preserved regions that encode ribosomal RNA and is separated by two conserved regions within the species, but vary fairly amongst species. Because of these regions are so preserved, specific primers work in a wide variety of taxa (Sumer et al., 2009). The rDNA-ITS2 sequences are useful as a general diagnosis technique for Trichogramma species. Before any character source can be proposed as appropriate for separating species, potential intraspecific variation must be taken into consideration (Stouthamer et al., 1999). rDNA-ITS2 and $\mathrm{COI}$ ensure a powerful tool for phylogenetics at low taxonomic levels (Cruickshank 2002).

Meksem and Kahl (2005) reported that polymorphism occurs naturally and depends on the variation in the DNA sequence, it also creates the basis of intra-species and inter-species variation in plant and animal genomes. The aim of this research was to determine whether current DNA techniques could differentiate intra-population genetic variation of these nine $T$. brassicae populations and other Trichogramma species present in GenBank database of National Center for Biotechnology Information (NCBI).

\section{MATERIALS AND METHODS}

\section{Trichogramma Cultures}

Corn fields which are infested with European corn borer, Ostrinia nubilalis (Hübner) in Düzce province have been identified and the populations of pests and egg parasitoids have been followed up by the weekly intervals since the first egg was determined. The collected $O$. nubilalis egg clusters were placed in glass tubes individually. The eggs were maintained at $25^{\circ} \mathrm{C}$ until European corn borer larvae and parasitoids emerged. After the parasitoids and larvae emergence are complete, the eggs are counted as parasitized and non-parasitized. Trichogramma species, which are emerged from parasitized eggs have continued to produce under laboratory conditions. Eggs of Ephestia kuehniella Zeller (Lepidoptera: Pyralidae) were used as hosts for this purpose. The obtained E. kuehniella eggs were glued onto cardboards as a daily. The cardboards containing the E. kuehniella eggs were placed in tubes with the Trichogramma adults and maintained in climatic chambers regulated at $25 \pm 1{ }^{\circ} \mathrm{C}, 70 \pm 5 \% \mathrm{RH}$, and 16:8 $\mathrm{h}$ photoperiod. About 9-10 days later, the Trichogramma adults began to appear. Insect culture was continued until the identification of the Trichogramma species was completed.

\section{DNA Extraction and PCR Amplification}

DNA was isolated as identified by Waeyenberge et al. (2000) with some revisions described follow; one to ten frozen parasitoids were crushed with a crusher into $45 \mu$ of distilled water ( $\left(\mathrm{ddH}_{2} \mathrm{O}\right.$ ) in $1.5 \mathrm{ml}$ eppendorf tube and the crushed parasitoid contents were centrifuged. After that $40 \mu \mathrm{l}$ of the sample mix were transferred to PCR tube comprising $50 \mu \mathrm{l}$ of WLB (Worm Lysis Buffer) and $10 \mu \mathrm{l}$ of Proteinase K (20 mg $\mathrm{ml}-1)$. The PCR tubes were frozen at $-80^{\circ} \mathrm{C}$ for at least 10 minute, then incubated at 65 for 1 hour and $95^{\circ} \mathrm{C}$ for 10 minute in a thermocycler. After, the tubes were 
Koca et al., Determination of the Genetic Variation within the Egg Parasitoid, Trichogramma brassicae, Bezdenko (Hymenoptera: Trichogrammatidae) Populations in Düzce Province, Turkey

centrifuged for 1 minute at $14000 \mathrm{rpm}$ and these extracted DNA samples were stored at $-20^{\circ} \mathrm{C}$ until PCR amplification (Waeyenberge et al., 2000).

The amplification of the rDNA-ITS region was carried out in a total $50 \mu \mathrm{l}$ reaction volume in PCR thermocycler. The reaction volume including that $30 \mu \mathrm{l}$ ddH2O, $15 \mu \mathrm{l}$ of Dream Taq PCR Master Mix (2X) (Fermentas Life Sciences, Germany), $1 \mu \mathrm{M}$ of each forward and reverse primer (Table 1), and $3 \mu$ of DNA. The PCR condition were initial denaturation for $3 \mathrm{~min}$ at $94{ }^{\circ} \mathrm{C}$; 35 cycles of $94{ }^{\circ} \mathrm{C}$ denaturation (45 s), $53{ }^{\circ} \mathrm{C}$ annealing (45 s) and $72{ }^{\circ} \mathrm{C}$ extension (45 s); a final extension for $3 \mathrm{~min}$ at $72{ }^{\circ} \mathrm{C}$. After PCR amplification, $10 \mu \mathrm{l}$ of each PCR product was mixed with $1 \mu \mathrm{l}$ of $6 \mathrm{X}$ loading buffer (Fermentas Life Sciences, Germany) and then loaded on a $1.5 \%$ standard TAE buffered agarose gel. After electrophoresis (100 V for $60 \mathrm{~min})$, the gel was stained with ethidium bromide $(0.1 \mu \mathrm{g} \mathrm{ml}-1)$ for 20 min, and visualized under UV-light and photographed. The remaining PCR products were kept at $-20{ }^{\circ} \mathrm{C}$ (Subbotin et al., 2003; Tanha Maafi et al., 2003).

\section{Sequencing}

The remainder of the PCR products were loaded on a $1 \%$ agarose gel for electrophoresis (100 V, $60 \mathrm{~min})$.
The purification method was done as defined in the manufacturer's instructions (Wizard ${ }^{\circledR}$ SV Gel and PCR Clean - Up System Kit, Promega). DNA from nine samples, representing nine populations, were sequenced in a sequencing facility (Refgen, Ankara, Turkey) in both directions to get matching sequences of both DNA strands. The sequences were formatted and evaluated. Eventually, all sequences were added to GenBank (Sequin v. 9.00, http://www.ncbi.nlm.nih.gov) and accession numbers were obtained for each population. The sequences of nine DNA samples from this research were placed in GenBank with accession numbers (Table 2).

\section{Phylogenetic Analysis}

The sequences of nine DNA samples were edited and alignments were made by CLUSTALW as implemented in BIOEDIT (Hall 1999). All aligned characters were implemented in the phylogenetic analysis. Phylogenetic trees were derived using maximum likelihood and this was constructed with using the MEGA v 7.0. (Kumar et al., 2016). The evolutionary history was inferred by using the Maximum Likelihood method based on the Kimura 2parameter model (Kimura 1980).

Table 1. Primers used in the amplification of DNA.

Çizelge 1. DNA amplifikasyonunda kullanulan primerler.

\begin{tabular}{lll}
\hline Primer & $\mathbf{5}^{\prime} \_\mathbf{3}^{\prime}$ & References \\
\hline Forward & TGTGAACTGCAGGACACATG & Staouthammer et al., 1999 \\
Reverse & GTCTTGCCTGCTCTGAG & Staouthammer et al., 1999 \\
\hline
\end{tabular}

Table 2. Identified Trichogramma brassicae and accession numbers.

Çizelge 2. Tanımlanan Trichogramma brassicae ve erişim numaraları.

\begin{tabular}{cllc}
\hline Sample No & \multicolumn{1}{c}{ Species } & Original Host & Accession Number \\
\hline 1 & Trichogramma brassicae & Ostrinia nubilalis & KX010935 \\
2 & Trichogramma brassicae & Ostrinia nubilalis & KX010936 \\
3 & Trichogramma brassicae & Ostrinia nubilalis & KX010937 \\
4 & Trichogramma brassicae & Ostrinia nubilalis & KX010938 \\
5 & Trichogramma brassicae & Ostrinia nubilalis & KX010939 \\
6 & Trichogramma brassicae & Ostrinia nubilalis & KX010940 \\
7 & Trichogramma brassicae & Ostrinia nubilalis & KX010941 \\
8 & Trichogramma brassicae & Ostrinia nubilalis & KX010942 \\
9 & Trichogramma brassicae & Ostrinia nubilalis & KX010943
\end{tabular}


Koca et al., Determination of the Genetic Variation within the Egg Parasitoid, Trichogramma brassicae, Bezdenko (Hymenoptera: Trichogrammatidae) Populations in Düzce Province, Turkey

\section{RESULTS AND DISCUSSION}

Trichogramma specimens were collected from corn fields in Düzce province of Turkey. Nine sequences were obtained from the Düzce samples and amplified partial sequences of the rDNA-ITS2 of Trichogramma samples by use the polymerase chain reaction (PCR). All tested populations were defined as T. brassicae. A general consensus sequence was derived from the obtained sequences and used for phylogenetic analysis. T. brassicae sequences were placed in GenBank with the numbers from KX010935 to KX010943 (Table 2). Dendograms were formed together with sequences of different Trichogramma species obtained from the GenBank.

The rDNA-ITS2 sequences of nine $T$. brassicae samples obtained from Düzce province were 100\% similarity to each other, in other words, there is no genetic variation among the populations (Figure 1.). However, when the samples belonging to $T$. brassicae in different countries (AY182766, JF920441, JF920451) available in GenBank database were compared with our samples, the similarity rate was found to be $62 \%$ (Figure 2.). In addition, these samples were most similar to T. evanescens, and were found to be quite different from other Trichogramma species.

Our results show that there is no genetic variation in $T$. brassicae populations. Parasitization rate obtained in different corn field in Düzce province is very high (98\%) and very close to each other (Kutuk 2016). This supports homogenity of identified $T$. brassicae population in Düzce province.

The rDNA-ITS2 is a significant molecular marker that can be used for comparing closely related subspecies, species and populations. The molecular method provides specific and precision results for the diagnosis of single and multiple species of egg parasitoids in agricultural systems (Sumer Ercan 2011).

Chang et al. (2001) sequenced the ITS1 region of Trichogramma chilonis and T. ostriniae species which are egg parasitic wasps of Asian corn borer (Ostrinia furnacalis Guenée). It was found that the two parasitic wasps were $86,1 \%$ similar. Alvarez and Hoy (2002) used the sequences of rDNA-ITS2 for separating populations of the parasitoid Ageniaspis citricola (Hymenoptera: Encyrtidae) from different geographical zones. Moreover, Thomson et al. (2003) studied the identification of Trichogramma species in southeastern Australia and used for ITS2 sequence analysis. It was found that the length of ITS2 is different for each species. Kumar et al. (2009) used the ITS2-RFLP method to distinguish 12 indigenous and exotic Trichogramma species in India. Sumer Ercan et al. (2011) reported that the differences between $T$. brassicae and $T$. euproctidis in their ITS2 sequence. Similarly, Sumer Ercan et al. (2013) analyzed that sequence variation of ITS2 examined differentiation of T. euproctidis and T. brassicae populations. Joeng et al. (2010) ITS2 gene sequences have been used to identify two Trichogramma species, $T$. ostriniae and $T$. brassicae, in Korea. Thiruvengadam et al. (2016) have studied the evolutionary relationships based on ITS2 gene of these species in order to identify Trichogramma species and to determine their differences.
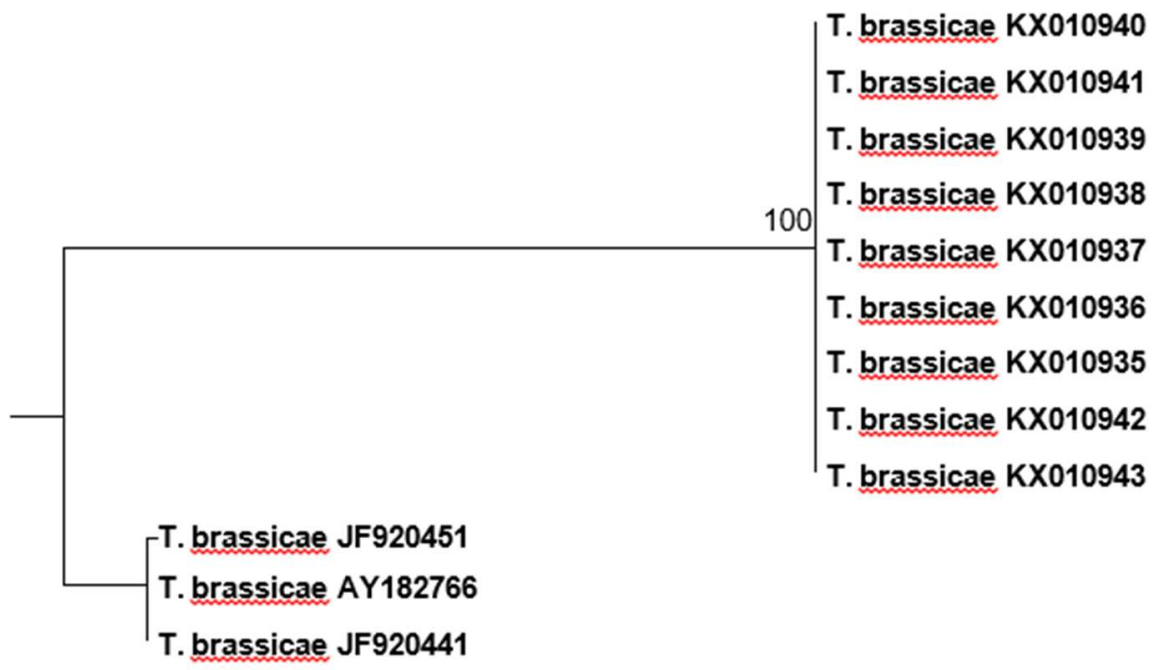

Figure 1. Phylogenetic tree (Maximum Likelihood) of $T$. brassicae sub-tree separately. Şekil 2. T. brassicae'nin alt dallarına ayrılmış filogenetik ağacı. 
Koca et al., Determination of the Genetic Variation within the Egg Parasitoid, Trichogramma brassicae, Bezdenko (Hymenoptera: Trichogrammatidae) Populations in Düzce Province, Turkey

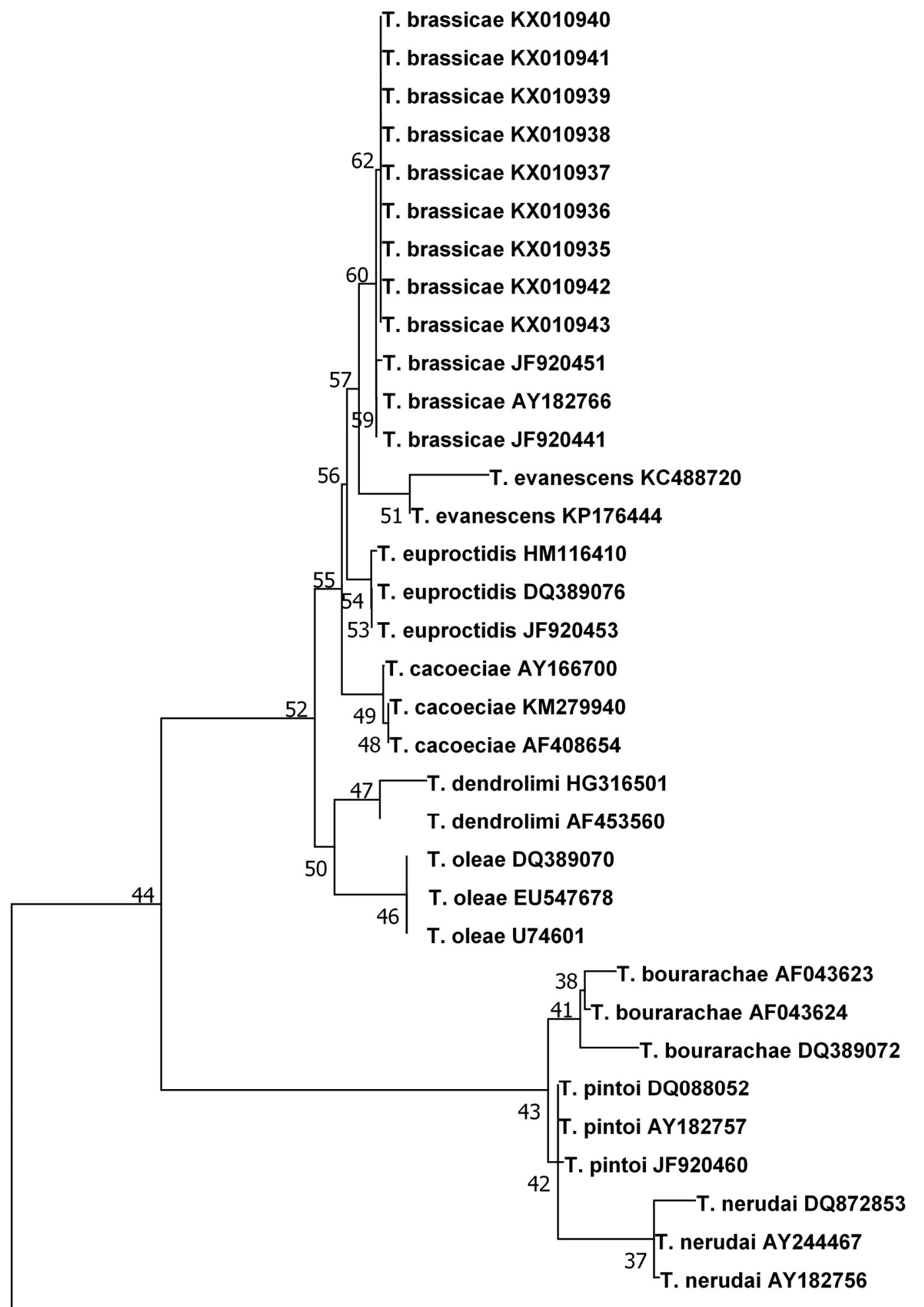

Eulophidae sp. KY047817

Figure 1. Phylogenetic tree created through the rDNA-ITS sequence alignment from nine T. brassicae populations. Eulophidae sp. is used as an outgroup.

Şekil 1. Dokuz T. brassicae popülasyonundan rDNA-ITS sekans grupları ile oluşturulan filogenetik ağaç. Eulophidae sp. grup dışı olarak kullanılmıştır. 
Koca et al., Determination of the Genetic Variation within the Egg Parasitoid, Trichogramma brassicae, Bezdenko (Hymenoptera: Trichogrammatidae) Populations in Düzce Province, Turkey

\section{CONCLUSION}

Trichogramma species are important biological agents in biological control programs. The choice of the appropriate natural enemy in the control of the target pest is very essential for reaching the successful biological control. Techniques based upon sequence analysis of the ITS2 locus of rDNA are used effectively in the identification of these species. Sequence analysis of the rDNA-ITS region of Trichogramma brassicae samples showed that the samples were genetically similar, but were quite different from other Trichogramma species. Genetic variations among different Trichogramma species are thought to be useful in the development of rapid diagnosis and detection methods based on PCR.

\section{REFERENCES}

Alvarez JM and Hoy MA., 2002. Evaluation of the ribosomal ITS2 DNA sequences in closely related populations of the parasitoid Ageniaspis (Hymenoptera: Encyrtidae). Annals of the Entomological Society of America, 95(2): 250-256.

Chang SC., Hu NT, Hsin CY and Sun CN., 2001. Characterization of differences between two Trichogramma wasps by molecular markers. Biol. Control. 21: 75-78.

Cruickshank RH., 2002. Molecular markers for the phylogenetics of mites and ticks. Systematic \& Applied Acarology, 7: 3-14.

Hall TA., 1999. BioEdit: A User-friendly Biological Sequence Alignment [ed.], and Analysis Program for Windows 95/98/NT. Nucleic Acids Symposium Series, 41: 95-98.

Jeong G., Kim H, Choi Y, Kim W, Park K, Bae S, Park K and Choi J., 2010. Molecular identification of two Trichogramma species (Hymenoptera: Trichogrammatidae) in Korea. Journal of Asia-Pacific Entomology, 13(1): 41-44.

Knutson A., 1998. The Trichogramma manual, Agricultural communication, The Texas A\&M University System, Texas, $42 \mathrm{pp}$.

Kimura M., 1980. A simple method for estimating evolutionary rate of base substitutions through comparative studies of nucleotide sequences. Journal of Molecular Evolution, 16: 111-120.

Kumar GA., Jalali SK, Venkatesan T, Stouthamer R, Niranjana $P$ and Lalitha Y., 2009. Internal transcribed spacer-2 restriction fragment length polymorphism (ITS-2-RFLP) tool to differentiate some exotic and indigenous trichogrammatid egg parasitoids in India. Biological control, 49(3): 207-213.

Kumar S., Stecher G and Tamura K., 2016 MEGA7: Molecular evolutionary genetics analysis version 7.0 for bigger datasets. Molecular Biology and Evolution, 33: 18701874.
Kutuk H., 2016. Identification and natural parasitism of Trichogramma species on Ostrinia nubilalis Hübner (Lepidoptera: Noctuidae) eggs in Düzce, Turkey. Entomological News, 126(4): 290-298.

Li Y., 1994. Worldwide use of Trichogramma for Biological Control on Different Crops: A survey. In: Wajnberg, E. and Hassan, S.A. (Eds.). Biological Control with Eggs Parasitoids. Center for Agriculture and Biosciences International. Wallingford, Great Britain. pp. 37-54.

Meksem K and Kahl G., 2005. The Handbook of Plant Genome Mapping, Genetic and Physical Mapping, WileyVCH, Weinheim, $380 \mathrm{p}$.

Nagarkatti S and Nagaraja h., 1977. Biosystematics of Trichogramma and Trichogrammatoidea species. Annual Review of Entomology, 22: 157-176.

Pinto JD and Stouthamer R., 1994. Systematics of the Trichogrammatidae with Emphasis on Trichogramma. In: Wajnberg E, Hassan SA (eds) Trichogramma and other Egg Parasitoids. CAB Intl., London, pp. 1-36.

Pinto JD., 1999. Systematics of the North American species of Trichogramma Westwood (Hymenoptera: Trichogrammmatidae). Memoirs of the Entomological Society of Washington, 22: 287-301.

Smith SM., 1996. Biological control with Trichogramma: advances, successes, and potential of their use. Annual Review of Entomology, 41: 375-406.

Smith SM and Hubbes M., 1986. Isoenzyme patterns and biology of Trichogramma minutum as influenced by rearing temperature and host. Entomologia Experimentalis et Applicata, 42: 249-258.

Stouthamer R., Hu J, van Kan FJPM, Platner GR and Pinto JD., 1999. The utility of Internally Transcribed Spacer 2 DNA sequences of the nuclear ribosomal gene for distinguishing sibling species of Trichogramma (Hymenoptera: Trichogrammatidae). BioControl, 43: 421440.

Subbotin SA., Sturhan D, Rumpenhorst HJ and Moens M., 2003. Molecular and morphological characterisation of the Heterodera avenae species complex (Tylenchida: Heteroderidae). Nematology, 5: 515-538.

Sumer F., Tuncbilek AS, Oztemiz S, Pintureau B, RugmanJones $P$ and Stouthamer R., 2009. A molecular key to the common species of Trichogramma of the Mediterranean region. BioControl, 54: 617-624.

Sumer Ercan F., Oztemiz S, Tuncbilek AS and Stouthamer R., 2011. Sequence analysis of the ribosomal DNA ITS2 region in two Trichogramma species (Hymenoptera: Trichogrammatidae). Archieves of Biological Sciences, 63(4), 949-954.

Sumer Ercan F., Oztemiz S and Tuncbilek A.S., 2013. Mitochondrial and ribosomal sequence analysis for discrimination of Trichogramma euproctis Girault and Trichogramma brassicae Bezdenko (Hymenoptera: 
Koca et al., Determination of the Genetic Variation within the Egg Parasitoid, Trichogramma brassicae, Bezdenko (Hymenoptera: Trichogrammatidae) Populations in Düzce Province, Turkey

Trichogrammatidae). Turkish Journal of Entomology, 37: 195-201.

Tanha Maafi Z., Subbotin SA and Moens M., 2003. Molecular identification of cyst forming nematodes (Heteroderidae) from Iran and a phylogeny based on ITSrDNA sequences. Nematology, 5: 99-111.

Thomson L., Rundle BJ, Carew ME and Hoffmann AA., 2003. Identification and characterization of Trichogramma species from south-eastern using the internal transcribed spacer 2 (ITS2) region of the ribosomal gene complex. Entomologia Experimentalis et Applicata, 106(3): 235-240.

Waeyenberge L., Ryss A, Moens M, Pinochet J and Vrain TC., 2000. Molecular characterization of 18 Pratylenchus species using rDNA restriction fragment length polymorphism. Nematology, 2: 135-2. 